\title{
Treatment of iatrogenic and traumatic tracheal disruptions
}

\author{
G. Leoncini1, L. Iurilli1, L. Boni2, G. Blanco1, \\ P. De Bellis 3 , G. Catrambone 1
}

ABSTRACT: Treatment of iatrogenic and traumatic tracheal disruptions. G. Leoncini, L. Iurilli, L. Boni, G. Blanco, P. De Bellis, G. Catrambone.

Background and aim. The optimal management of tracheal disruptions is still controversial. It is usually postulated that lesions wider than 1 or 2 centimetres and/or lesions of full-thickness should be treated by surgery at an early stage. Such a statement is not supported by any proven evidence. On the contrary, the conservative management of such injuries has also produced very good results according to recent reports. The aim of this study is to investigate whether conservative treatment can be safely used for wide tracheal lacerations and to assess any possible association between clinical features and modality of treatment.

Methods. Records of all patients with iatrogenic and traumatic tracheal disruptions observed between January 1992 and December 2006 were collected and retrospectively reviewed. Data regarding mechanism of injury, clinical and morphological features and modalities of treatment were registered. All possible associations between clinical features and modalities of treatment were investigated.

Results. 23 patients were observed overall. There were 6 males and 17 females with a median age of 58 years (range 20-84 yrs). 15 patients had undergone single tube intubation. One patient had his trachea injured during an esophagectomy. Ruptures were secondary to blunt $(n=5)$ and open $(n=2)$ trauma in 7 patients. Lesions varied in length between 1 and 7 centimetres (median length 3 centimetres) and all were full-thickness. The time interval until diagnosis varied between 0 and 72 hours (median 6 hours). Respiratory failure was evident in 7 patients. 16 patients $(69.5 \%)$ with lacerations ranging in length between 1 and 5.5 centimetres (median length $2.75 \mathrm{~cm}$ ) underwent conservative treatment. Seven patients $(30.5 \%)$ underwent surgery. The follow up was completed for 16 patients and varied between 15 and 105 months (median 22.5). One patient died after surgical treatment. No mortality or late major sequelae were registered after conservative treatment. Female sex, absence of respiratory failure and delayed diagnosis was associated with the conservative treatment.

Conclusions. Conservative treatment can play a major role even in cases of wide tracheal lacerations. Clinical rather than morphological features should be regarded as main criteria for treatment. The conservative treatment is particularly indicated in the case of stable respiratory parameters independent of the size and the depth of the lesion. Monaldi Arch Chest Dis 2008; 69: 3, 119-127.

Keywords: Thoracic trauma, Tracheal injuries, Conservative treatment, Intubation.

1 Unit of Thoracic Surgery, San Martino University Hospital, Genoa;

2 SS Clinical Trials, IST, Genoa;

3 Unit of Anesthesiology and Intensive Care, San Martino University Hospital, Genoa, Italy.

Correspondence: Dr. Giacomo Leoncini, U. O. Chirurgia Toracica, Azienda Ospedaliera Universitaria "San Martino", L.go R. Benzi 10, 16132 Genova, Italy; e-mail: giacomo.leoncini@hsanmartino.it

\section{Introduction}

Tracheal disruptions are usually considered as life threatening conditions, responsible for potentially fatal, acute or late complications if not approached early by surgery [1-8]. Nonetheless, the optimal management of such injuries is still controversial [9]. The surgical treatment has not been prospectively compared with other approaches and indications on treatment come from retrospective analyses based on small and heterogeneous groups of patients. As a consequence, there is no proven evidence to support the principle that surgery should be considered as the gold standard of treatment, whereas the role of conservative management is not established and criteria for surgical or conservative management are lacking.
Most authors consider the size and the depth of the lesion as a major criterion, advocating surgery for any long full-thickness laceration independent of different criteria such as clinical features. Accordingly, only small, non full-thickness iatrogenic injuries are usually deemed suitable for conservative management [1-9]. Nonetheless, a few cases and a few recent series have been reported with even wide full-thickness iatrogenic tracheal lacerations successfully managed by means of conservative treatment [10-17]. As far as traumatic ruptures are concerned, surgical treatment is advocated in most cases as well [18-19], but the conservative treatment has been reported also [20-25].

The conservative management has the potential advantage of avoiding the surgical-related morbidity and mortality, particularly in patients 
with multiple co-morbidities and/or the severely injured [26]. It could then represent a valuable alternative to surgery in selected patients if it turned out effective and free from major complications. All tracheal disruptions observed at the San Martino University Hospital Unit of Thoracic Surgery during a time period of 15 years underwent nonsurgical treatment whenever possible. The results of such a strategy are reviewed in order to investigate whether conservative treatment can be safely used and to assess any possible association between clinical features and modality of treatment.

\section{Materials and methods}

\section{Population}

The data of all patients referred to the Emergency Department and Trauma Centre of the San Martino University Hospital between January 1992 and December 2006 was retrospectively reviewed and records of all patients with a diagnosis of iatrogenic or traumatic tracheal disruption were collected. Data regarding patients age and sex, mechanism of injury, time interval between early symptoms and diagnosis, site and length of the laceration, view of the oesophagus or the mediastinal tissue through the lesion, symptoms, evidence of respiratory failure, presence of co-morbidities or associated traumatic lesions and treatment modalities were registered. Patients with tracheoesophageal fistulas were excluded.

\section{Assessment}

A fiberoptic bronchoscopy was performed in all patients to confirm the diagnosis and to assess the site, the extension and the morphology of the lesion. A CT scan of the chest was performed in all patients to investigate the possible evidence of associated lesions and/or cervical or mediastinal collections. In a few cases, in the presence of clinical suspicion, an oesophagoscopy was performed in order to rule out a possible concomitant oesophageal perforation. $\mathrm{Pa}-$ tients with multiple traumas also underwent a CT scan of both the abdomen and the head.

\section{Treatment}

Both surgical and conservative procedures were used. The surgical treatment was accomplished by collar cervicotomy for lesions involving the larynx and the upper half of the trachea and right thoracotomy for lesions involving the lower half of the trachea and the mainstem bronchus. Extubation took place as early as possible at the end of the procedure.

The conservative regimen consisted of broad spectrum antibiotics, airways humidification, cough sedatives and intermittent oxygen if needed. Oral intake of food was withheld for the initial few days in order to prevent episodes of "ab ingestis" and cough. Particular attention was payed to analgesia in patients with multiple rib fractures. Partial resolution of subcutaneous emphysema was occasionally achieved, if needed, by means of multiple small subcutaneous catheters. Electrocardiogram, heart rate, non-invasive blood pressure, pulse oximetry and body temperature were monitored. Blood gas values were achieved daily and blood cell count on alternate days. Chest $\mathrm{x}$-rays were also monitored. No endoscopy was usually performed during the initial days to avoid cough and further tracheal injury, with the exception of a few patients where doubt arose as to whether the lesion was not going to have a favourable outcome. In most cases the evolution was followed based on clinical parameters.

Tracheal intubation, without tracheotomy, was part of conservative treatment in 6 patients. The tube position was checked endoscopically in all cases with the cuff slightly inflated as distal to the rupture as possible in order to "bridge" the lesion. This was not possible in one case with a 4 centimetres long laceration of the distal trachea involving the origin of the right mainstem bronchus. The tube was then endoscopically placed just over the carina and the cuff minimally inflated adjacent to the lesion. The Intensive Care Unit was in charge of such patients. Invasive monitoring was performed according to the underlying diseases. Body temperature, blood cell count and the chest $\mathrm{x}$-ray were monitored. A larger number of endoscopies were performed overall to check the cuff position and/or to remove the secretions above and below the cuff. Broad spectrum antibiotics were administered. Time of extubation depended on when the lesion appeared on endoscopy to be healed and/or the underlying disease improved and made it possible to wean the patients from ventilator.

\section{Follow-up}

A fiberoptic bronchoscopy was performed in all patients before discharge. The first control was then scheduled one month later. The subsequent follow-up was made by means of outpatient examinations and endoscopic controls.

\section{Statistical methods}

The association between clinical features and treatment modalities was tested by means of the chi-square test for heterogeneity, or Fisher's exact test when appropriate. The Student's $t$ test was used for means comparisons. $P$ values are 2 -sided. All statistical analyses were performed with SAS 9.1 (SAS Institute Inc., Cary, NC, USA).

\section{Results}

\section{Population}

23 patients were observed overall. There were 6 males and 17 females with a median age of 58 years (range 20-84 years). Fifteen patients had undergone single tube tracheal intubation for elective surgery $(n=10)$ and for respiratory distress or cardiopulmonary resuscitation $(n=5)$. One patients experienced a tracheal laceration during dissection for esophagectomy. Traumatic ruptures were observed in 7 patients, secondary to blunt trauma in 5 patients and to open trauma in two. Details of 23 patients are summarised in table 1. 
TREATMENT OF IATROGENIC AND TRAUMATIC TRACHEAL DISRUPTIONS

\begin{tabular}{|c|c|c|c|c|c|c|c|c|c|}
\hline $\mathbf{N}^{\circ}$ & Age/Sex & Mechanism & Site/Lenght & $\begin{array}{c}\text { Intubated } \\
\text { at presentation }\end{array}$ & $\begin{array}{l}\text { Respiratory } \\
\text { failure }\end{array}$ & $\begin{array}{l}\text { Associated traumas/ } \\
\text { Co-morbidities }\end{array}$ & $\begin{array}{l}\text { Time interval } \\
\text { to diagnosis (hrs) }\end{array}$ & Treatment & $\begin{array}{c}\text { Follow-up (months) } \\
\text { Outcome }\end{array}$ \\
\hline 1 & $84 / \mathrm{F}$ & $\begin{array}{l}\text { Intubation } \\
\text { (elective) }\end{array}$ & $\begin{array}{c}\text { MT } \\
5,5 \mathrm{~cm}\end{array}$ & no & no & no & 12 & Conservative & $\begin{array}{c}17 \\
\text { Dilated trachea }\end{array}$ \\
\hline 2 & $63 / \mathrm{F}$ & $\begin{array}{l}\text { Intubation } \\
\text { (elective) }\end{array}$ & $\begin{array}{c}\text { MT } \\
3,5 \mathrm{~cm}\end{array}$ & no & no & no & 2 & Conservative & $\begin{array}{c}33 \\
\text { Plan scar }\end{array}$ \\
\hline 3 & $77 / \mathrm{F}$ & $\begin{array}{l}\text { Intubation } \\
\text { (elective) }\end{array}$ & $\begin{array}{c}\text { MT } \\
4,5 \mathrm{~cm}\end{array}$ & no & yes & Diabetes mellitus & 12 & $\begin{array}{l}\text { Conservative } \\
\text { (intubation) }\end{array}$ & $\begin{array}{c}22 \\
\text { NT }\end{array}$ \\
\hline 4 & $62 / \mathrm{M}$ & $\begin{array}{c}\text { Surgery } \\
\text { (esophagect.) }\end{array}$ & $\begin{array}{c}\text { MT } \\
3,5 \mathrm{~cm}\end{array}$ & yes & no & no & 0,5 & Surgical & $\begin{array}{c}15 \\
\text { NT }\end{array}$ \\
\hline 5 & $48 / \mathrm{F}$ & $\begin{array}{l}\text { Intubation } \\
\text { (elective) }\end{array}$ & $\begin{array}{l}\mathrm{MT}+\mathrm{RMB} \\
\quad 4 \mathrm{~cm}\end{array}$ & no & yes & no & 1 & Surgical & $\begin{array}{c}51 \\
\text { NT }\end{array}$ \\
\hline 6 & $70 / \mathrm{F}$ & $\begin{array}{l}\text { Intubation } \\
\text { (emergency) }\end{array}$ & $\begin{array}{l}\text { MT } \\
3 \mathrm{~cm}\end{array}$ & yes & no & $\begin{array}{c}\text { Vascular disease } \\
\text { Hypertension, Stroke }\end{array}$ & 12 & $\begin{array}{l}\text { Conservative } \\
\text { (intubation) }\end{array}$ & $\begin{array}{c}15 \\
\text { NT }\end{array}$ \\
\hline 7 & $59 / \mathrm{M}$ & $\begin{array}{l}\text { Intubation } \\
\text { (emergency) }\end{array}$ & $\begin{array}{l}\text { MT } \\
5 \mathrm{~cm}\end{array}$ & yes & yes & MI & 6 & Surgical & $\begin{array}{c}19 \\
\text { Eupnoic } \\
\text { (no endoscopy) }\end{array}$ \\
\hline 8 & $40 / \mathrm{M}$ & $\begin{array}{l}\text { Intubation } \\
\text { (elective) }\end{array}$ & $\begin{array}{l}\text { MT } \\
5 \mathrm{~cm}\end{array}$ & no & yes & no & 1 & Surgical & $\begin{array}{c}63 \\
\mathrm{NT}\end{array}$ \\
\hline 9 & $73 / \mathrm{F}$ & $\begin{array}{l}\text { Intubation } \\
\text { (elective) }\end{array}$ & $\begin{array}{c}\mathrm{CT}+\mathrm{MT} \\
2 \mathrm{~cm}\end{array}$ & no & no & no & 0,5 & Conservative & $\begin{array}{l}\text { Discharged } \\
\text { Lost }\end{array}$ \\
\hline 10 & $58 / \mathrm{F}$ & $\begin{array}{l}\text { Intubation } \\
\text { (elective) }\end{array}$ & $\begin{array}{l}\text { MT } \\
2 \mathrm{~cm}\end{array}$ & no & no & no & 12 & Conservative & $\begin{array}{c}82 \\
\text { NT }\end{array}$ \\
\hline 11 & $43 / \mathrm{F}$ & $\begin{array}{c}\text { Intubation } \\
\text { (emergency) }\end{array}$ & $\begin{array}{c}\mathrm{CT} \\
2 \mathrm{~cm}\end{array}$ & no & no & no & 48 & Conservative & $\begin{array}{c}57 \\
\text { NT }\end{array}$ \\
\hline 12 & $67 / \mathrm{M}$ & $\begin{array}{l}\text { Intubation } \\
\text { (emergency) }\end{array}$ & $\begin{array}{l}\text { MT } \\
3 \mathrm{~cm}\end{array}$ & yes & no & $\begin{array}{l}\text { MI, vascular disease, } \\
\text { hypertension }\end{array}$ & 72 & $\begin{array}{l}\text { Conservative } \\
\text { (intubation) }\end{array}$ & $\begin{array}{c}23 \\
\text { NT }\end{array}$ \\
\hline 13 & $20 / \mathrm{F}$ & $\begin{array}{l}\text { Intubation } \\
\text { (elective) }\end{array}$ & $\begin{array}{l}\text { MT } \\
3 \mathrm{~cm}\end{array}$ & no & no & no & 12 & Conservative & $\begin{array}{l}105 \\
\text { NT }\end{array}$ \\
\hline 14 & $78 / \mathrm{F}$ & $\begin{array}{l}\text { Intubation } \\
\text { (elective) }\end{array}$ & $\begin{array}{l}\text { MT } \\
2 \mathrm{~cm}\end{array}$ & no & no & no & 2 & Conservative & $\begin{array}{c}21 \\
\text { NT }\end{array}$ \\
\hline 15 & $54 / \mathrm{F}$ & $\begin{array}{l}\text { Intubation } \\
\text { (elective) }\end{array}$ & $\begin{array}{c}\mathrm{CT}+\mathrm{MT} \\
4 \mathrm{~cm}\end{array}$ & no & no & no & 6 & Conservative & $\begin{array}{r}29 \\
\text { NT }\end{array}$ \\
\hline 16 & $77 / \mathrm{F}$ & $\begin{array}{c}\text { Intubation } \\
\text { (emergency) }\end{array}$ & $\begin{array}{l}\text { MT } \\
2 \mathrm{~cm}\end{array}$ & yes & no & $\begin{array}{c}\text { COPD } \\
\text { Diabetes, Dementia }\end{array}$ & 72 & $\begin{array}{l}\text { Conservative } \\
\text { (intubation) }\end{array}$ & $\begin{array}{l}\text { Discharged } \\
\text { Lost }\end{array}$ \\
\hline 17 & $31 / \mathrm{M}$ & $\begin{array}{c}\text { PI } \\
\text { (gunshot) }\end{array}$ & $\begin{array}{c}\text { Larynx + CT } \\
1,5 \mathrm{~cm}\end{array}$ & $\begin{array}{c}\text { yes } \\
\text { (tracheostomy) }\end{array}$ & no & Mediastinitis & 0 & Surgical & $\begin{array}{c}\text { Discharged } \\
\text { Substen. Dysph. } \\
\text { Lost }\end{array}$ \\
\hline 18 & $59 / \mathrm{F}$ & $\begin{array}{c}\text { PI } \\
\text { (blade) }\end{array}$ & $\begin{array}{c}\text { CT } \\
1,5 \mathrm{~cm}\end{array}$ & no & yes & Thyroid injury & 0 & Surgical & $\begin{array}{l}\text { Discharged } \\
\text { Lost }\end{array}$ \\
\hline 19 & $28 / \mathrm{F}$ & BCT & $\begin{array}{c}\text { Larynx + CT } \\
1 \mathrm{~cm}\end{array}$ & no & no & no & 1 & Conservative & $\begin{array}{c}15 \\
\text { Dysphonia }\end{array}$ \\
\hline 20 & $30 / \mathrm{F}$ & BTT & $\begin{array}{l}\text { MT } \\
4 \mathrm{~cm}\end{array}$ & yes & yes & $\begin{array}{l}\text { Cerebral injury } \\
\text { Liver rupture } \\
\text { Multiple fractures }\end{array}$ & 18 & $\begin{array}{l}\text { Conservative } \\
\text { (intubation) }\end{array}$ & $\begin{array}{l}\text { Discharged } \\
\text { Lost }\end{array}$ \\
\hline 21 & $41 / \mathrm{F}$ & BTT & $\begin{array}{c}\text { MT } \\
2,5 \mathrm{~cm}\end{array}$ & no & no & Multiple rib fractures & 24 & Conservative & $\begin{array}{l}\text { Discharged } \\
\text { Lost }\end{array}$ \\
\hline 22 & $24 / \mathrm{F}$ & BTT & $\begin{array}{c}\mathrm{MT}+\mathrm{MRB}+ \\
\mathrm{ULB}+\mathrm{IB} \\
7 \mathrm{~cm}\end{array}$ & yes & yes & Liver and spleen ruptures & 18 & Surgical & Exitus \\
\hline 23 & $34 / \mathrm{M}$ & $\mathrm{BCT}$ & $\begin{array}{c}\text { CT } \\
2 \mathrm{~cm}\end{array}$ & yes & no & no & 6 & $\begin{array}{l}\text { Conservative } \\
\text { (intubation) }\end{array}$ & $\begin{array}{c}15 \\
\text { NT }\end{array}$ \\
\hline
\end{tabular}


Site, morphology and clinical features

The site of the ruptures is reported in table 1 . Lesions varied in length between 1 and 7 centimetres (median length 3 centimetres). All the iatrogenic lacerations consisted of a linear tear of the posterior wall of the trachea, sometimes within the angle between the membranous and the cartilaginous walls. A linear laceration also occurred in four cases after blunt trauma (cases 19, 20, 21 and 23). A complex rupture of the distal trachea, the right main bronchus, the upper bronchus take off and the intermediate bronchus was observed after blunt chest injury (case 22). One transverse laceration resulted from the perforation of the anterior aspect of the thyroid gland and the cervical trachea by the blade of scissors (case 18). Finally, one laceration secondary to a gunshot perforating the larynx and the cervical trachea resulted in a complex and irregular rupture (case 17). Full-thickness lacerations were observed in all cases. Gaping during ventilation and view of the oesophagus and/or the mediastinal tissue were evident in 17 and 14 cases respectively. The time interval between the early symptoms and the diagnosis varied between 0 and 72 hours (median 6 hrs). Evidence of respiratory failure (7 patients) and presence of associated traumas and/or co-morbidities (10 patients) are reported in table 1. Subcutaneous and mediastinal em- physema were present in nearly all cases. Pneumothorax was evident in two cases (cases 5 and 22). Other symptoms were emoftoe and bleeding (case 18) and dysphonia and pain (case 19).

\section{Modality of treatment}

Sixteen patients $(69.5 \%)$ underwent conservative treatment. Ten patients were breathing spontaneously at time of diagnosis with respiratory parameters keeping good and stable or with minimal respiratory distress (table 2). Gaping during ventilation or view of the oesophagus and/or the mediastinal tissue through the lesion were evident in 7 patients. All these patients were managed by means of full conservative measures without intubation.

Six patients underwent conservative treatment with intubation (table 3). Gaping during ventilation or view of the oesophagus and/or the mediastinal tissue through the lesion were evident in 5 patients. A 77 years old lady (case 3) presented with massive subcutaneous emphysema, respiratory distress and severe hypoxia 12 hours after elective abdominal surgery. She had a 4.5 centimetres disruption of the mediastinal trachea. She was considered as high surgical risk due to medical comorbidities. Re-intubation was then performed under the guide of the fiberscope with the tip of the tube just over the carina.

Table 2. - Summary of 10 patients who were breathing spontaneously at presentation. Tracheal lacerations were managed by full conservative measures (without intubation)

\begin{tabular}{|c|c|c|c|c|c|c|c|c|}
\hline $\mathbf{N}^{\circ}$ & Age/Sex & Mechanism & Site/Lenght & $\begin{array}{l}\text { Gaping/View of } \\
\text { mediastinal tissue }\end{array}$ & $\begin{array}{l}\text { Respiratory } \\
\text { failure }\end{array}$ & $\begin{array}{c}\text { Co-morbidities } \\
\text { Associated traumas }\end{array}$ & $\begin{array}{l}\text { Time to diagnosis } \\
\text { (hours) }\end{array}$ & $\begin{array}{c}\text { Follow-up (months) } \\
\text { Outcome }\end{array}$ \\
\hline 1 & $84 / F$ & $\begin{array}{l}\text { Intubation } \\
\text { (surgery) }\end{array}$ & $\begin{array}{l}\text { MT } \\
5,5 \mathrm{~cm}\end{array}$ & Yes & No & No & 12 & $\begin{array}{c}17 \\
\text { Dilated trachea }\end{array}$ \\
\hline 2 & $63 / F$ & $\begin{array}{l}\text { Intubation } \\
\text { (surgery) }\end{array}$ & $\begin{array}{c}\text { MT } \\
3,5 \mathrm{~cm}\end{array}$ & Yes & No & No & 2 & $\begin{array}{c}33 \\
\text { Plan scar }\end{array}$ \\
\hline 9 & $73 / \mathrm{F}$ & $\begin{array}{l}\text { Intubation } \\
\text { (surgery) }\end{array}$ & $\begin{array}{l}\mathrm{CT}+\mathrm{MT} \\
2 \mathrm{~cm}\end{array}$ & No & No & No & 0,5 & $\begin{array}{l}\text { Discharged } \\
\text { Lost }\end{array}$ \\
\hline 10 & $58 / \mathrm{F}$ & $\begin{array}{l}\text { Intubation } \\
\text { (surgery) }\end{array}$ & $\begin{array}{l}\text { MT } \\
2 \mathrm{~cm}\end{array}$ & Yes & No & No & 12 & $\begin{array}{c}82 \\
\text { NT }\end{array}$ \\
\hline 11 & $43 / \mathrm{F}$ & $\begin{array}{l}\text { Intubation } \\
\text { (br. asthma) }\end{array}$ & $\begin{array}{l}\mathrm{CT} \\
2 \mathrm{~cm}\end{array}$ & Yes & No & No & 48 & $\begin{array}{l}57 \\
\text { NT }\end{array}$ \\
\hline 13 & $20 / \mathrm{F}$ & $\begin{array}{l}\text { Intubation } \\
\text { (surgery) }\end{array}$ & $\begin{array}{l}\text { MT } \\
3 \mathrm{~cm}\end{array}$ & Yes & No & No & 12 & $\begin{array}{l}105 \\
\text { NT }\end{array}$ \\
\hline 14 & $78 / \mathrm{F}$ & $\begin{array}{l}\text { Intubation } \\
\text { (surgery) }\end{array}$ & $\begin{array}{l}\text { MT } \\
2 \mathrm{~cm}\end{array}$ & No & No & No & 2 & $\begin{array}{l}21 \\
\text { NT }\end{array}$ \\
\hline 15 & $54 / \mathrm{F}$ & $\begin{array}{l}\text { Intubation } \\
\text { (surgery) }\end{array}$ & $\begin{array}{c}\mathrm{CT}+\mathrm{MT} \\
4 \mathrm{~cm}\end{array}$ & Yes & No & No & 6 & $\begin{array}{l}29 \\
\text { NT }\end{array}$ \\
\hline 19 & $28 / \mathrm{F}$ & BCT & $\begin{array}{c}\text { Larynx }+\mathrm{CT} \\
1 \mathrm{~cm}\end{array}$ & No & No & No & 1 & $\begin{array}{c}15 \\
\text { Dysphonia }\end{array}$ \\
\hline 21 & $41 / \mathrm{F}$ & BTT & $\begin{array}{c}\text { MT } \\
2,5 \mathrm{~cm}\end{array}$ & Yes & No & Multiple rib fracture & 24 & $\begin{array}{l}\text { Discharged } \\
\text { Lost }\end{array}$ \\
\hline
\end{tabular}

BCT: blunt cervical trauma; BTT: blunt thoracic trauma; MT: mediastinal trachea; CT: cervical trachea; NT: normal trachea. 
Table 3. Summary of 6 patients with tracheal disruptions managed by conservative measures with intubation

\begin{tabular}{|c|c|c|c|c|c|c|c|c|c|}
\hline $\mathbf{N}^{\circ}$ & Age/Sex & Mechanism & Site/Lenght & $\begin{array}{l}\text { Gaping/View of } \\
\text { mediastinal tissue }\end{array}$ & $\begin{array}{l}\text { Intubated } \\
\text { at presentation }\end{array}$ & $\begin{array}{l}\text { Respiratory } \\
\text { failure }\end{array}$ & $\begin{array}{l}\text { Co-morbidities } \\
\text { Associated traumas dias }\end{array}$ & $\begin{array}{l}\text { Time to } \\
\text { liagnosis (hrs) }\end{array}$ & $\begin{array}{l}\text { Follow-up (months) } \\
\text { Outcome }\end{array}$ \\
\hline 3 & $77 / F$ & $\begin{array}{l}\text { Intubation } \\
\text { (surgery) }\end{array}$ & $\begin{array}{c}\text { MT } \\
4,5 \mathrm{~cm}\end{array}$ & Yes & No & Yes & Diabetes & 12 & $\begin{array}{c}22 \\
\text { NT }\end{array}$ \\
\hline 6 & $70 / \mathrm{F}$ & $\begin{array}{l}\text { Intubation } \\
\text { (stroke) }\end{array}$ & $\begin{array}{l}\text { MT } \\
3 \mathrm{~cm}\end{array}$ & Yes & Yes & No & $\begin{array}{l}\text { Vascular disease } \\
\text { Hypertension }\end{array}$ & 12 & $\begin{array}{l}15 \\
\text { NT }\end{array}$ \\
\hline 12 & $67 / \mathrm{M}$ & $\begin{array}{l}\text { Intubation } \\
\text { (MI) }\end{array}$ & $\begin{array}{l}\text { MT } \\
3 \mathrm{~cm}\end{array}$ & Yes & Yes & No & $\begin{array}{l}\text { MI, Vascular disease } \\
\text { Hypertension }\end{array}$ & 72 & $\begin{array}{l}23 \\
\text { NT }\end{array}$ \\
\hline 16 & $77 / \mathrm{F}$ & $\begin{array}{l}\text { Intubation } \\
\text { ("ab ingestis") }\end{array}$ & $\begin{array}{l}\text { MT } \\
2 \mathrm{~cm}\end{array}$ & No & Yes & No & $\begin{array}{l}\text { COPD, diabetes, } \\
\text { dementia }\end{array}$ & 72 & $\begin{array}{l}\text { Discharged } \\
\text { Lost }\end{array}$ \\
\hline 20 & $30 / \mathrm{F}$ & BTT & $\begin{array}{l}\text { MT } \\
4 \mathrm{~cm}\end{array}$ & Yes & Yes & Yes & $\begin{array}{l}\text { Brain trauma, liver } \\
\text { injury, multiple fractures }\end{array}$ & es 18 & $\begin{array}{l}\text { Discharged } \\
\text { Lost }\end{array}$ \\
\hline 23 & $34 / \mathrm{M}$ & $\mathrm{BCT}$ & $\begin{array}{l}\mathrm{CT} \\
2 \mathrm{~cm}\end{array}$ & Yes & Yes & No & No & 6 & $\begin{array}{l}15 \\
\text { NT }\end{array}$ \\
\hline
\end{tabular}

BTT: blunt thoracic trauma; BCT: blunt cervical trauma; MT: mediastinal trachea; CT: cervical trachea; MI: miocardial infarction; NT: normal trachea.

Five patients were already intubated at presentation. The indication for intubation was an underlying medical disease in cases $6,12,16$ and a multiple trauma in case 20. Intubation was actually the cause of the tracheal laceration in three patients (cases 6, 12 and 16). Only one patient (case 23) was intubated elsewhere because of the tracheal laceration, with the intention of securing the airway during the transfer. Suitable tube positioning without any technical problem was achieved in 4 patients (cases 6,12, 16 and 23). A young woman was referred to the emergency department with multiple trauma and shock (case 20). Subcutaneous emphysema and respiratory failure were evident. The whole body CT scan showed a massive hemoperitoneum due to a wide laceration of the right liver. An emergency laparotomy for liver repairing was then performed. At the end of such procedure we were called due to increasing subcutaneous emphysema and to difficulty in ventilating the patient. A fiberoptic bronchoscopy showed a 4 centimetres long laceration, involving the distal membranous trachea and the right main stem bronchus takeoff. The surgical treatment was considered to be at very high risk due to the hemodynamic and metabolic impairment. An attempt was then made to achieve acceptable ventilation until the hemodynamic and metabolic parameters hopefully stabilized, and the patient could undergo the surgical procedure with more favourable conditions. The tube was then endoscopically placed just over the carina and the cuff minimally inflated adjacent to the lesion. Small air leaks were tolerated and sufficient ventilation was achieved. Bronchial toilette and correct tube re-positioning were performed during the subsequent hours by means of repeated bronchoscopies. Ventilation remained effective during the following hours and actually improved; finally the spontaneous healing of the laceration occurred.
Seven patients $(30.5 \%)$ underwent surgical treatment as reported in table 4. Respiratory failure was the main indication for surgery in 5 of them. One patient (case 4) had his trachea injured during dissection for esophagectomy while intubated with a double lumen tube. Primary repair was easily performed through the same field of operation. One patient (case 17) had an emergency tracheostomy performed elsewhere, which guaranteed effective ventilation. After a few days an upper mediastinal collection occurred and the patient was referred to our unit. The tracheostomy site was cleaned and upper mediastinal debriment was performed. The airway's continuity was restored secondly by means of laryngotracheal resection and reconstruction. The patient was finally discharged with substenosis and dysphonia.

The morphological and clinical features of patients according to conservative or surgical treatment are reported in table 5. The characteristics significantly associated with the treatment modality were sex and evidence of respiratory failure ( $p=0.02$ and $<0.01$, respectively). Moreover, the two groups of patients differed by average time to diagnosis (12 hrs in the conservative group vs. 1 hrs in the surgical group, $p=0.02$ ).

\section{Outcome}

All patients who underwent full conservative treatment (table 2) were discharged in good health. Minor sequelae were reported in 2 patients. The follow up was completed for 8 patients and it ranges between 15 and 105 months (median time 31 months). No late sequelae were observed. All patients managed by intubation recovered (table 3 ). The follow up was completed for 4 patients and it ranged between 15 and 23 months (median time of follow up 18.5 months). No late sequelae were 
observed. One patient died due to ARDS and multiorgan failure after dehiscence of primary repair and subsequent right pneumonectomy (case 22). Among the others who underwent surgery (table 4), the follow up was completed for four patients who underwent primary repair without early and late sequelae (follow up ranging from 15 to 63 months, with a median of 35 months).

\section{Discussion}

Both standard and fascinating innovative surgical procedures have been largely proposed as the gold standard of therapy for wide and/or full thickness tracheal disruptions $[1-9,27,28]$, in order to prevent severe acute or late complications such as respiratory failure, purulent mediastinitis and ventilation disorders $[3,4,6,7,18,29]$. Such a statement is not supported by any proven evidence and should, in our opinion, be reconsidered.

The present series is one of the largest reported recently on this subject, introducing a different approach to tracheal injuries. All patients were not subjected to surgery whenever possible, basing on clinical rather than on morphological features. The evidence of respiratory failure and/or severe comorbidities were regarded as the main criteria for the choice of treatment. As a result, 16 patients, out of $23(69,5 \%)$, with tracheal lacerations ranging in length between 1 and 5.5 centimetres (median length $2,75 \mathrm{~cm}$ ), were successfully treated by means of conservative measures without major sequelae. These results compare favourably with similar ones reported recently by Conti and Coll [14] and Gomez-Caro and Coll. [15].

The observation of even wide, full-thickness lacerations in otherwise stable patients, with minimal respiratory impairment is not infrequent. Major air leaks are probably prevented in such cases by the proximity of the oesophageal wall or the mediastinal tissue. Ten patients were observed with stable respiratory parameters in spite of wide full-thickness lacerations in our series. The incidence of respiratory failure at presentation was $30.4 \%$ overall ( 7 out of 23 ). The percentage reduced to $25 \%$ (4 out of 16) within the group of the iatrogenic disruptions. An even lower incidence was recently reported by Gomez-Caro and Coll. (1 out of 18 patients) [15]. Furthermore, respiratory failure is not the clear, nor the main indication for surgery in many surgical series, in which stable patients are reported to have undergone surgery $[1-4,6,9,27,28]$. The median length of ruptures that underwent surgery was higher in our series when compared to that of lesions managed conservatively (table 5). Nonetheless the indication for surgery was not represented by the length per sè but by the evidence of respiratory failure.

As far as other expected complications are concerned $[1,4,7,9,18,29,30]$, they seem to be of quite rare occurrence, as we reported and in accordance with all recent series or case reports on

Table 4. - Summary of 7 patients with tracheal disruptions managed by surgical treatment

\begin{tabular}{|c|c|c|c|c|c|c|c|c|}
\hline $\mathbf{N}^{\circ}$ & Age/Sex & Mechanism & Site/Lenght & $\begin{array}{l}\text { Respiratory } \\
\text { failure }\end{array}$ & $\begin{array}{l}\text { Associated traumas/ } \\
\text { Co-morbidities }\end{array}$ & $\begin{array}{l}\text { Time interval to } \\
\text { diagnosis (hrs) }\end{array}$ & $\begin{array}{l}\text { Modality } \\
\text { of treatment }\end{array}$ & $\begin{array}{c}\text { Follow up (months) } \\
\text { Outcome }\end{array}$ \\
\hline 4 & $62 / \mathrm{M}$ & $\begin{array}{c}\text { Surgery } \\
\text { (esophagectomy) }\end{array}$ & $\begin{array}{c}\text { MT } \\
3,5 \mathrm{~cm}\end{array}$ & no & no & 0,5 & $\begin{array}{c}\text { Thoracotomy } \\
\text { Repair }\end{array}$ & $\begin{array}{l}15 \\
\text { NT }\end{array}$ \\
\hline 5 & $48 / \mathrm{F}$ & $\begin{array}{l}\text { Intubation } \\
\text { (elective) }\end{array}$ & $\begin{array}{c}\mathrm{MT}+\mathrm{RMB} \\
\quad 4 \mathrm{~cm}\end{array}$ & yes & no & 1 & $\begin{array}{c}\text { Thoracotomy } \\
\text { Repair }\end{array}$ & $\begin{array}{l}51 \\
\text { NT }\end{array}$ \\
\hline 7 & $59 / \mathrm{M}$ & $\begin{array}{l}\text { Intubation } \\
\text { (emergency) }\end{array}$ & $\begin{array}{l}\text { MT } \\
5 \mathrm{~cm}\end{array}$ & yes & MI & 6 & $\begin{array}{c}\text { Thoracotomy } \\
\text { Repair }\end{array}$ & $\begin{array}{c}19 \\
\text { Eupnoic } \\
\text { (no endoscopy) }\end{array}$ \\
\hline 8 & $40 / \mathrm{M}$ & $\begin{array}{l}\text { Intubation } \\
\text { (elective) }\end{array}$ & $\begin{array}{l}\text { MT } \\
5 \mathrm{~cm}\end{array}$ & yes & no & 1 & $\begin{array}{c}\text { Thoracotomy } \\
\text { Repair }\end{array}$ & $\begin{array}{l}63 \\
\text { NT }\end{array}$ \\
\hline 17 & $31 / \mathrm{M}$ & $\begin{array}{c}\text { PI } \\
\text { (gunshot) }\end{array}$ & $\begin{array}{c}\text { Larynx }+ \text { CT } \\
1,5 \mathrm{~cm}\end{array}$ & no & Mediastinitis & 0 & $\begin{array}{l}\text { Cervicotomy } \\
\text { Debriment } \\
\text { Subsequent } \\
\text { laryngotracheal } \\
\text { resection and } \\
\text { recontruction }\end{array}$ & $\begin{array}{c}\text { Discharged } \\
\text { (substenosis } \\
\text { and dysphonia) } \\
\text { Lost }\end{array}$ \\
\hline 18 & $59 / \mathrm{F}$ & $\begin{array}{c}\text { PI } \\
\text { (blade) }\end{array}$ & $\begin{array}{c}\text { CT } \\
1,5 \mathrm{~cm}\end{array}$ & yes & Tyroid injury & 0 & $\begin{array}{c}\text { Cervicotomy } \\
\text { Repair }\end{array}$ & $\begin{array}{l}\text { Discharged } \\
\text { Lost }\end{array}$ \\
\hline 22 & $24 / F$ & BTT & $\begin{array}{c}\mathrm{MT}+\mathrm{MRB}+ \\
\mathrm{ULB}+\mathrm{IB} \\
7 \mathrm{~cm}\end{array}$ & yes & $\begin{array}{l}\text { Liver and spleen } \\
\text { ruptures }\end{array}$ & 18 & $\begin{array}{l}\text { Thoracotomy } \\
\text { Repair } \\
\text { Subsequent right } \\
\text { pneumonectomy }\end{array}$ & Exitus \\
\hline
\end{tabular}

PI: penetrating injury; BTT: blunt thoracic trauma; MT: mediastinal trachea; RMB: right main bronchus; CT: cervical trachea; ULB: upper lobe bronchus; IB: intermediate bronchus; MI: miocardial infarction; NT: normal trachea. 
Table 5. - Morphological and clinical features according to the modality of treatment

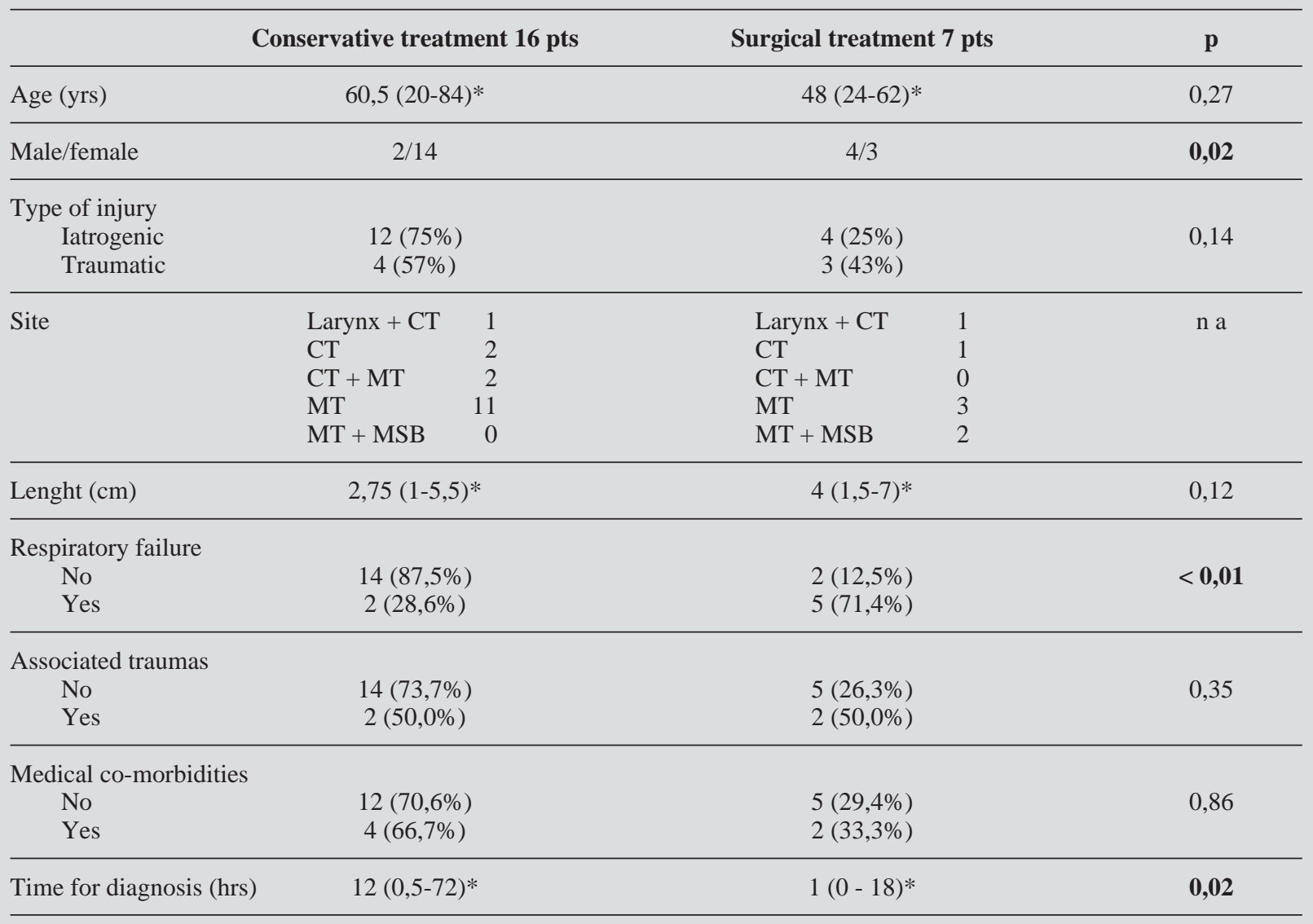

*: median value (range); CT: cervical trachea; MT: mediastinal trachea; MSB: main stem bronchus.

conservative treatment of tracheobronchial disruptions [10-17, 20, 26]. The broad-spectrum antibiotics administration, together with the drainage of the peri-lesional infection into the airway itself, are probably effective in preventing a purulent mediastinitis. On the other hand, stenosis seems unlikely to occur after linear longitudinal lacerations of the trachea or the main bronchi, which is the prevalent appearance of iatrogenic lesions but which can occur also after blunt traumatic disruptions.

Intubation was prolonged in all patients who were already intubated at presentation (table 3 ). In one patient (case 23) the choice was made to prolong the intubation, even if the patient probably could have been extubated. Four patients needed ventilation due to the underlying disease (cases 6, 12 and 16) and to a multiple trauma (case 20). They were deemed unfit for surgery due to comorbidities. We used intubation as primary treatment only in one patient (case 3). Even if intubation was not the choice treatment in our series, it should be noted that conservative treatment with intubation can be effective in managing critical patients, resulting in good outcomes even in cases of wide tracheal lacerations.

Mechanical ventilation is usually possible in such cases, provided that the cuff can be inflated distally to the lesion. Attention must be given to ensure the cuff is not overinflated in order to avoid possible lesion enlargement. Minimal air leaks can be tolerated. Repeated endoscopies may be needed.

Surgical repair is usually unavoidable if the laceration involves the distal trachea or the mainstem bronchi. Nonetheless, in case of significant co-morbidities and very high surgical risk, one could be induced to make a further attempt at the conservative treatment. That is what happened with one patient in our series (case 20). It should be noted that we abstained from surgery with the belief that the patient would have to undergo to the operation on a second time. Unexpectedly, the lesion healed spontaneously. Such experience, even if occasional, strengthened our confidence in the airways "self-repairing" potential.

A brilliant solution was recently reported by Conti and Coll., who were able to conservatively treat six high surgical risk patients with lesions involving the distal trachea or the mainstem bronchi. Selective bilateral mainstem bronchus intubation was performed with $6 \mathrm{~mm}$ endotracheal tubes passed through a large tracheostomy. All patients survived [14].

Mortality rates as high as $60 \%$ are reported after surgical treatment of tracheal disruptions [2, 5, 30, 31]. Co-morbidities and/or underlying severe clinical conditions may significantly affect the overall mortality rate after surgery. The conservative treatment is of particular value in this setting. Recently reported data analysis regarding post-intubation tracheal disruptions suggests that high 
mortality rates result both from the underlying clinical condition (intubation for medico-surgical emergencies vs. intubation for elective surgery) but also, independent of the reason for intubation, from the method of treatment, with an overall trend toward a higher mortality in patients managed surgically [14]. Furthermore, Kuhne and Coll. have recently outlined the value of the conservative management in reducing the overall morbidity in patients with multiple injuries [26].

As far as traumatic disruptions are concerned, the conservative treatment is usually reported to play a very minor role, if any. Surgical treatment has been reported by Cassada and coll. and Richardson in two series of 11 and 33 patients respectively $[18,19]$. Different mechanisms of rupture, leading to complex and irregularly shaped disruptions, with frequent involvement of major bronchi and, consequently, with higher incidence of complications, account for the minor role of the conservative measures in this setting [18-19].

Nonetheless, the same criteria for possible conservative treatment can be used as for disruptions of iatrogenic origin. Traumatic disruptions underwent surgical treatment more frequently than iatrogenic ones in our series $(3 / 7,42,8 \%$ vs $4 / 16$, $25 \%$ ) (table 5). Nonetheless, conservative measures were successfully used in 4 patients with ruptures ranging in length between 1 and 4 centimetres (cases 19, 20, 21 and 23). Such experience, even if limited to four cases, couples with previously reported series in suggesting that the conservative treatment plays a role in traumatic disruptions [20-26].
The conservative treatment significantly associated with a delayed diagnosis in our series (table 5). However, keeping 12 hours as the time limit between early and late diagnosis, no difference was seen overall in the average length of lesions between the two groups of patients $(\mathrm{cm} \mathrm{2.9 \pm 1.4} \mathrm{SD}$ vs. $\mathrm{cm} 3.5 \pm 1.4 \mathrm{SD}, \mathrm{p}=0.37$ ). Based on these observations, we can presume that patients undergoing delayed diagnosis have ruptures that are most suitable for conservative modalities of treatment.

A significant association was also observed between the conservative treatment and the female sex (table 5). That is not surprising as female patients are known to be prone to post-intubation injuries more frequently than males $[2,3,5,13,29$, 30] and iatrogenous disruptions are most likely to benefit from conservative treatment than traumatic ones, as reported by us (table 5) and by most previous studies [10-17].

Based on our experience, we propose an algorythm as a general guide for the treatment of tracheal disruptions (figure 1). A few patients could not be entered into this flow-chart due to particular conditions. For instance, two patients underwent surgery in our series in the absence of respiratory failure (in case 4 the lesion occurred during surgery and it was promptly repaired, in case 17 surgery was performed due to the upper mediastinitis) and four patients were intubated in the absence of respiratory failure (patients 6, 12 and 16 were already intubated and needed ventilation due to the underlying disease, patient 23 was already intubated and we were cautious in extubate him). Furthermore, it must be underlined that abstention

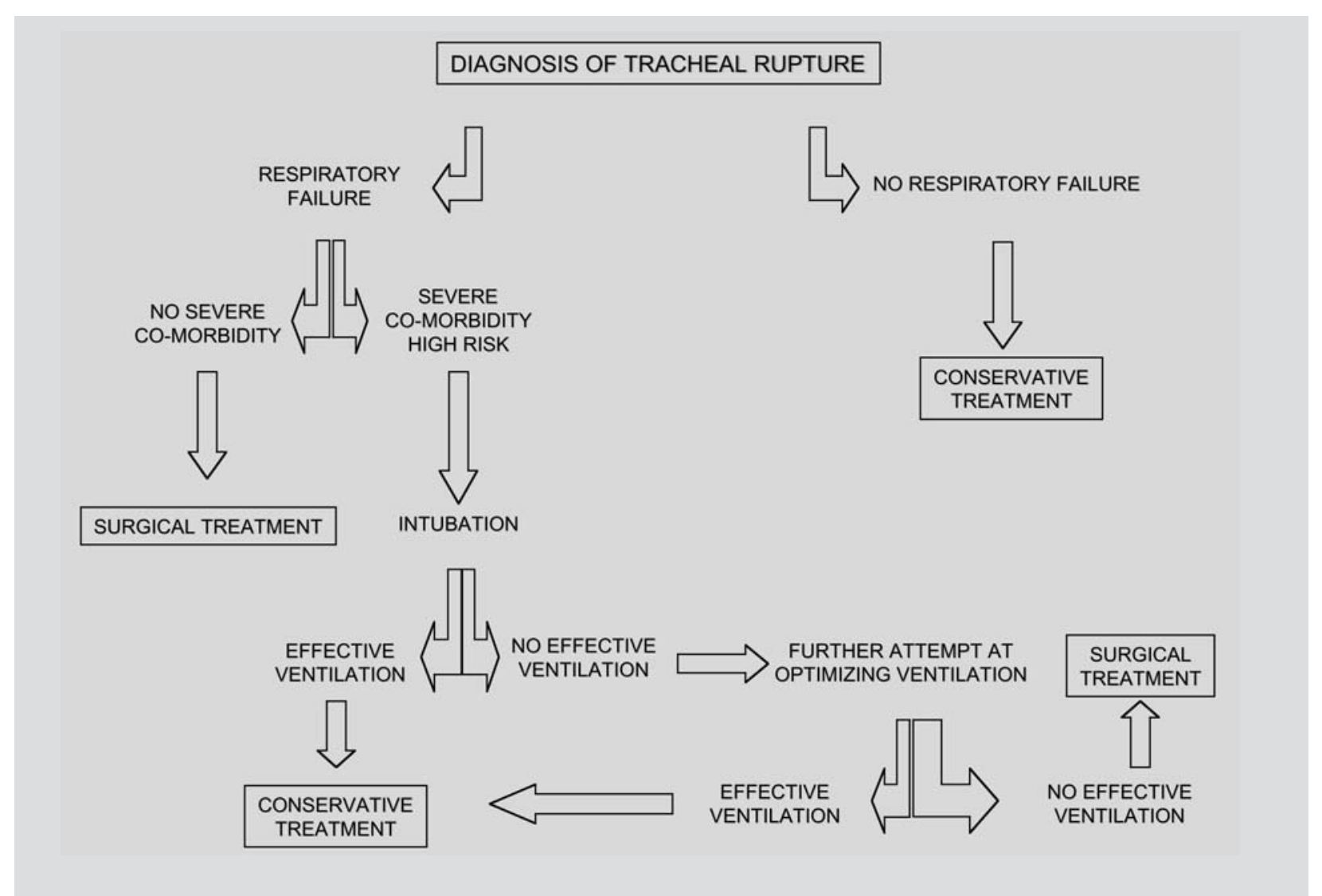

Fig. 1. - A possible algorythm for the treatment of tracheal disruptions. 
from surgery was a waiting policy in all cases for the lesions undergoing spontaneous healing, and surgery would be proceeded in the case of worsening of respiratory parameters. Nonetheless, no surgical procedure resulted from the failure of the initial conservative regimen.

In conclusion, the conservative treatment should be considered for all cases of tracheal disruption, regardless the length or the depth of lacerations, provided that the patient has stable respiratory parameters while breathing spontaneously or can be ventilated effectively if intubation is needed. Delayed diagnosis seems to be a further criterion in favour of conservative treatment. The latter should be strongly recommended in patients with severe co-morbidities and high surgical risk. An experienced thoracic surgical setting is advisable for the management of such patients in the case that surgical treatment became unavoidable.

\section{References}

1. Gabor $\mathrm{S}$, Renner $\mathrm{H}$, Pinter $\mathrm{H}$, et al. Indications for surgery in tracheobronchial ruptures. Eur J Cardiothorac Surg 2001; 20: 399-404.

2. Kaloud H, Smolle-Juettner FM, Prause G, List WF. Iatrogenic ruptures of the tracheobronchial tree. Chest 1997; 112: 774-778.

3. Borasio P, Ardissone F, Chiampo G. Post-intubation tracheal rupture. A report of ten cases. Eur J Cardiothorac Surg 1997; 12: 98-100.

4. Mussi A, Ambrogi MC, Ribechini A, Lucchi M, Menconi F, Angeletti CA. Acute major airway injuries: clinical features and management. Eur J Cardiothorac Surg 2001; 20: 46-52.

5. Hofmann HS, Rettig G, Radke J, Neef H, Silber RE. Iatrogenic ruptures of the tracheobronchial tree. Eur $J$ Cardiothorac Surg 2002; 21: 649-652.

6. Carbognani P, Bobbio A, Cattelani L, Internullo E, Caporale D, Rusca M. Management of postintubation membranous tracheal rupture. Ann Thorac Surg 2004; 77: 406-409.

7. Liu H, Jahr JS, Sullivan E, Waters PF. Tracheobronchial rupture after double-lumen endotracheal intubation. J Cardiothorac Vasc Anesth 2004; 18: 228-233.

8. Sippel M, Putensen C, Hirner A, Wolff M. Tracheal rupture after endotracheal intubation: experience with management in 13 cases. Thorac Cardiovasc Surg 2006; 54: 51-56.

9. Leinung S, Mobius C, Hofmann H-S, et al. Iatrogenic tracheobronchial ruptures - treatment and outcomes. Interact Cardiovasc Thorac Surg 2006; 5: 303-306.

10. D'Odemont JP, Pringot J, Goncette L, Goenen M, Rodenstein DO. Spontaneous favourable outcome of tracheal laceration. Chest 1991; 99: 1290-1292.

11. Ross HM, Grant FJ, Wilson RS, Burt ME. Nonoperative management of tracheal laceration during endotracheal intubation. Ann Thorac Surg 1997; 63: 240-242.

12. Molins L, Buitrago LJ, Vidal G. Conservative treatment of tracheal lacerations secondary to endotracheal intubation. Ann Thorac Surg 1997; 64: 1227-1228.
13. Jougon J, Ballester M, Choukroun E, Dubrez J, Reboul G, Velly JF. Conservative treatment for postintubation tracheobronchial rupture. Ann Thorac Surg 2000; 69: 216-220.

14. Conti M, Pougeoise M, Wurtz A, et al. Management of postintubation tracheobronchial ruptures. Chest 2006; 130: 412-418.

15. Gomez-Caro A, Ausin P, Moradiellos FJ, et al. Role of conservative medical management of tracheobronchial injuries. J Trauma 2006; 61: 1426-1435.

16. Mercadante E, Giovannini C, Castaldi F, et al. Major iatrogenic tracheal injury during pneumonectomy: conservative treatment. Ann Thorac Surg 2006; 81: 22852287.

17. Griffo S, Stassano P, Fraioli G, Monaco M, Cicalese M, Di Tommaso L. Tracheal injury during pneumonectomy: semi-conservative treatment. $J$ Thorac Cardiovasc Surg 2007; 133: 827-828.

18. Cassada DC, Munyikwa MP, Moniz MP, Dieter RA, Schuchmann GF, Enderson BL. Acute injuries of the trachea and major bronchi: importance of early diagnosis. Ann Thorac Surg 2000; 69: 1563-1567.

19. Richardson JD. Outcome of tracheobronchial injuries: a long-term perspective. J Trauma 2004; 56: 30-36.

20. Ngakane H, Muckart DJ, Luvuno FM. Penetrating visceral injuries of the neck: results of a conservative management policy. Br J Surg 1990; 77: 908-910.

21. Roxburgh JC. Rupture of the tracheobronchial tree. Thorax 1987; 42: 681-688.

22. De La Rocha AG, Kayler D. Traumatic rupture of the tracheobronchial tree. Can J Surg 1985; 28: 68-71.

23. Scott Jones W, Mavroudis C, Richardson D, Gray LA, Howe R. Management of tracheobronchial disruption resulting from blunt trauma. Surgery 1984; 95: 319322.

24. Velly JF, Martigne C, Moreau JM, Dubrez J, Kerdi S, Couraud L. Post traumatic tracheobronchial lesions. A follow up study of 47 cases. Eur J Cardiothorac Surg 1991; 5: 352-355.

25. Self ML, Mangram A, Berne JD, Villareal D, Norwood $\mathrm{S}$. Nonoperative management of severe tracheobronchial injuries with positive end-expiratory pressure and low tidal volume ventilation. J Trauma 2005; 59: 1072-1075.

26. Kuhne CA, Kaiser GM, Flohe S, et al. Nonoperative management of tracheobronchial injuries in severely injured patients. Surg Today 2005; 35: 518-523.

27. Massard G, Rougè C, Dabbag A, et al. Tracheobronchial lacerations after intubation and tracheostomy. Ann Thorac Surg 1996; 61: 1483-1487.

28. Angelillo-Mackinlay T. Transcervical repair of distal membranous tracheal laceration. Ann Thorac Surg 1995; 59: 531-532.

29. Lancelin C, Chapelier AR, Fadel E, Macchiarini P, Dartevelle PG. Transcervical-transtracheal endoluminal repair of membranous tracheal disruptions. Ann Thorac Surg 2000; 70: 984-986.

30. Marty-Ané CH, Picard E, Jonquet O, Mary H. Membranous tracheal rupture after endotracheal intubation. Ann Thorac Surg 1995; 60: 1367-1371.

31. Meyer M. Iatrogenic tracheobronchial lesions - A report on 13 cases. Thorac Cardiovasc Surg 2001; 49: 115-119. 